4. Salter DM, Hughes DE, Simpson R, Gardner DL: Integrin expression by human articular chondrocytes. $\mathrm{Br} \mathrm{J}$ Rheumatol 31:231-234, 1992

5. Guo J, Jourdian GW, MacCallum DK: Culture and growth characteristics of chondrocytes encapsulated in alginate beads. Conn Tissue Res 19:277-297, 1989

6. Jobanputra P, Corrigall V, Kingsley G, Panayi G: Cellular responses to human chondrocytes: absence of allogeneic responses in the presence of HLA-DR and ICAM-1. Clin Exp Immunol 90:336-344, 1992

7. Loeser RF, Carlson CS, McGee MP: Expression of $\beta 1$ integrins by cultured articular chondrocytes and in osteoarthritic cartilage. Exp Cell Res 217:248-257, 1995

8. LaFlamme SE, Akiyama S, Yamada K: Regulation of fibronectin receptor distribution. J Cell Biol 117:437-447, 1992

9. Dalton SL, Marcantonio EE, Associan RK: Cell attachment controls fibronectin and $\alpha 5 \beta 1$ integrin levels in fibroblasts. J Biol Chem 267:8186-8191, 1992

10. Woods VL Jr, Schreck PJ, Gesink DS, Pacheco IIO, Amiel D, Akeson WH, Lotz M: Integrin expression by human articular chondrocytes. Arthritis Rheum 37:537-544, 1994

\section{Monocyte apoptosis in patients with active lupus}

The presence of nucleosome polymers in the peripheral blood of patients with active systemic lupus erythematosus (SLE) (1) suggests ongoing apoptosis. While the lymphocyte population has been implicated as a source of these fragments (2), the cells that release the chromatin are incompletely charactcrized. Our group has reported that patients with active lupus have a $T$ cell subset which spontaneously lyses autologous macrophages in vitro (3), and that murine $T$ cells capable of inducing apoptosis in syngeneic macrophages will cause a lupus-like disease in vivo (4). These results suggest that monocyte/macrophage apoptosis may occur in patients with active lupus. We therefore sought to determine whether patients with active lupus have evidence of ongoing monocyte apoptosis.

Patients with active lupus were recruited from the inpatient rheumatology service and outpatient clinics at the
University of Michigan, and paticnts with inactive lupus and active rheumatoid arthritis (RA) were recruited from the outpatient clinics. Healthy control subjects were obtained by advertising. Patients met the American College of Rheumatology (formerly, the American Rheumatism Association) criteria for the classification of SLE (5) or RA (6). SLE and RA activity were defined as previously described (3). Paticnts receiving cyclophosphamide were excluded from study. Some samples were stored as heparinized whole blood overnight at $23^{\circ} \mathrm{C}$. In these cases, care was taken to store both patient and control samples under identical conditions. All samples were analyzed within 20 hours of phlebotomy.

To detect apoptotic cells, peripheral blood mononuclear cells (PBMC) were isolated as described (3), and stained with propidium iodide (PI) and Hoescht 33342, and then analyzed by flow cytometry $(7,8)$. The lymphocyte, monocyte, and granulocyte populations were identified by forward and $90^{\circ}$ light scatter and confirmed by staining with anti-CD3FITC, anti-B1-FITC, and anti-MO1-FITC (Coulter, Hialeah, FL). Dead cells were identified by high PI staining, viable cells by low PI staining and 2N Hoescht DNA staining, and apoptotic cells by low PI staining and less than $2 \mathrm{~N}$ Hoescht DNA staining $(7,8)$. Where indicated, $\mathrm{T}$ cells were depleted by rosetting with sheep erythrocytes (3), and the nonrosetting population was fixed and analyzed by transmission electron microscopy (TEM) as described (4). Differences between groups were tested by analysis of variance, using SYST $\Lambda T$ software (Evanston, IL), or by $t$-tests.

PBMC were obtained from 10 patients with active SLE, 8 patients with inactive SLE, 7 patients with active RA, and 12 healthy controls. The cells were stained as described above, and the percentages of apoptotic monocytes and lymphocytes were determined by flow cytometry. Figure 1A shows a representative histogram of monocytes from a healthy control. Figure 1B shows monocytes from a patient with active lupus analyzed similarly. In Figure 1B, the population of cells excluding PI, and containing less DNA than controls by Hoescht staining, contains the apoptotic cells $(7,8)$.

Figure $2 \mathrm{~A}$ shows that an average of $5 \%$ of the mono-
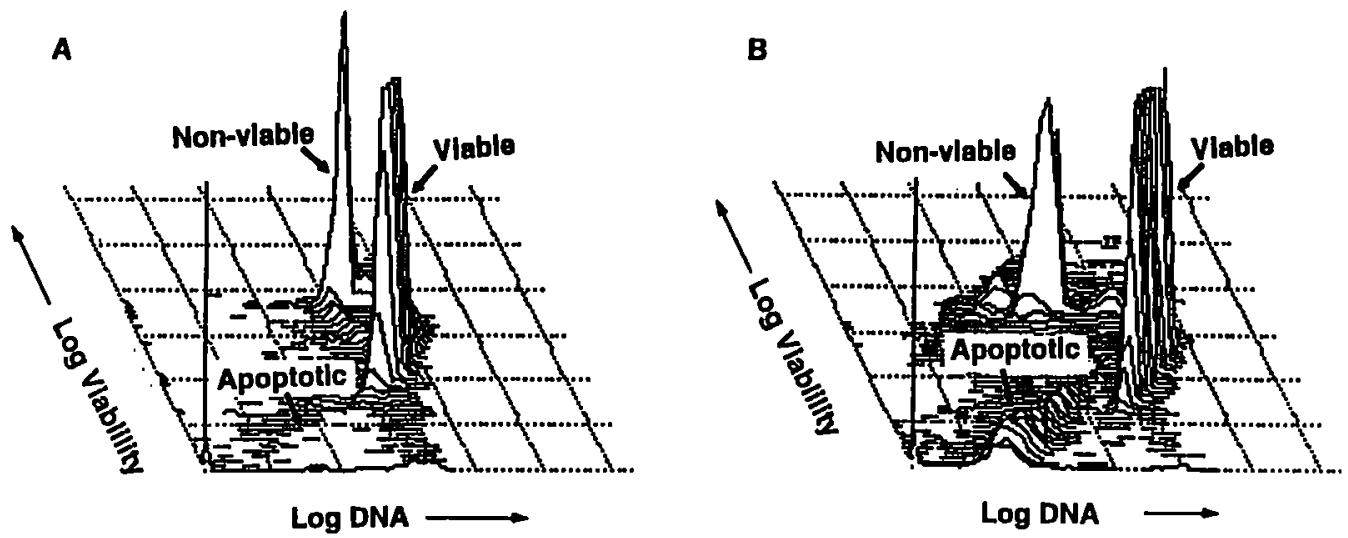

Figure 1. Peripheral blood mononuclear cells from $\mathbf{A}$, a healthy control and $\mathbf{B}$, a patient with active lupus were stained with anti-MO1-FIIC, propidium iodide, and Hoescht 33342 and analyzed using 3-color flow cytometry. The monocyte population is shown. The $x$ axis (Log DNA) represents the intensity of the Hocscht staining; the $y$ axis (Log Viability) represents the PI staining intensity. The unlabelled $z$ (vertical) axis represents the cell number. 
A.

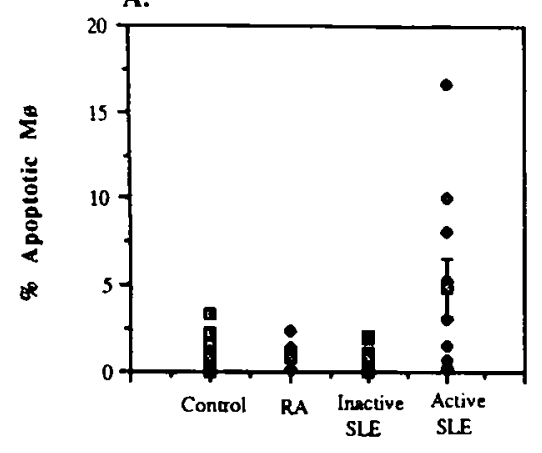

c.

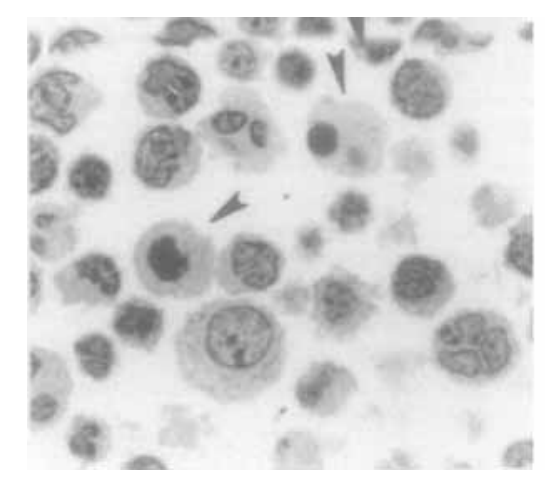

B.

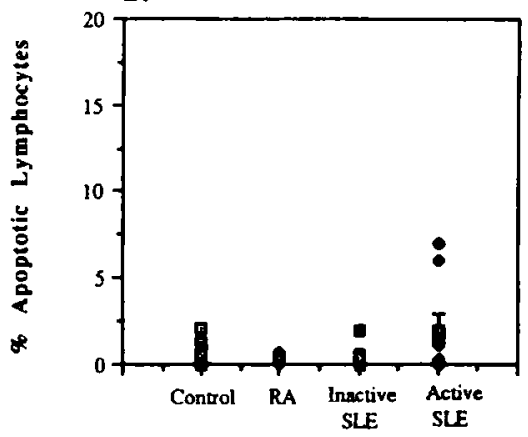

D.

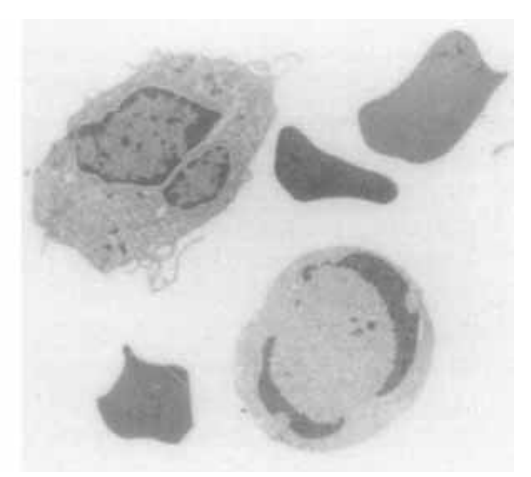

Figure 2. A, Monocyte (M $\phi)$ apoptosis was measured by flow cytometry in peripheral blood mononuclear cells isolated from the indicated groups. Each point represents an individual subject; squares with I-bars represent the mean \pm SEM of the subjects within each group. Patients with active systemic lupus erythematosus (SLE) had a greater percentage of monocytes undergoing apoptosis than did controls $(P=0.007)$. B, Lymphocyte apoptosis in the same subjects. The increase in lymphocyte apoptosis in the lupus patients was not significant at the $P<$ 0.05 level. C, Non-T cells from a patient with active lupus, stained with toluidine bluc. Arrowheads identify apoptotic monocytes (magnification $\times 1,000$ ). D. Non- $T$ cells from a lupus patient, stained with uranyl acetate and imaged by transmission electron microscopy. Three erythrocytes and 2 monocytes are shown; one of the monocytes is apoptotic (magnification $\times 3,200$ ). $\mathrm{RA}=$ rheumatoid arthritis.

cytes from patients with active lupus were undergoing apoptosis, while $<1 \%$ of monocytes from the other subjects were apoptotic $(P=0.007)$. Figure $2 \mathrm{~B}$ shows that a lesser number of lymphocytes from the same subjects were apoptotic, with an average of $2 \%$ for the patients with active SLE and $\leq 0.6 \%$ for the other groups. However, this difference was not statistically significant $(P=0.06)$, possibly due to the number of subjects analyzed.

Since some of the lupus patients had received corticosteroids, the effect of methylprednisolone on monocyte apoptosis was examined. Blood samples were obtained before and after administration of $1 \mathrm{gm}$ of methylprednisolone. No significant increases were observed immediately (mean \pm SEM $0.85 \pm 0.35 \%$ before and $1.75 \pm 1.34 \%$ after, $n=2$ ) or up to 3 days later $(1.2 \%$ versus $0.5 \%)$. Furthermore, 5 of the SLE patients receiving a mean \pm SEM of $54 \pm 7.6 \mathrm{mg} /$ day of prednisone had only $0.34 \pm 0.16 \%$ apoptotic monocytes. Overall, the level of monocyte apoptosis was $4.2 \pm 1.9 \%$ in patients receiving $\leq 15 \mathrm{mg}$ of prednisone/day, and $1.9 \pm 1.0 \%$ in patients receiving $>15 \mathrm{mg} /$ day $(P>0.20)$. This finding supports the notion that corticosteroids do not stimulate monocyte apoptosis.

The presence of apoptotic monocytes was confirmed by morphology in 2 subjects with active SLE. Figure $2 \mathrm{C}$ shows a representative micrograph of freshly obtained and isolated non-T cells stained with toluidine bluc from one of these subjects, and 2D shows a TLM image. Monocytic cells show nuclear condensation, which is characteristic of apoptotic cells. Such cells were not seen in similar preparations from a normal subject (data not shown). To further examine the relationship between discase activity and monocyte apoptosis, two subjects with active SLE and increased numbers of circulating apoptotic monocytes were retested following therapy and with remission of symptoms. In both subjects, the percentage of apoptotic monocytes decreased (from $8.1 \%$ to $0 \%$, and from $10 \%$ to $3.1 \%)$.

A recent report described accelerated lymphocyte apoptosis in patients with active SLE (2). However, other cell types 
were excluded from analysis in this study. Our results suggest that monocytes are also dying by apoptosis in patients with active lupus. Since some of the samples were analyzed 16-20 hours after phlebotomy, it is possible that some degree of apoptosis began between the time of phlebotomy and the time of staining. However, in SLE patient samples analyzed within hours of phlebotomy, apoptotic monocytes were also seen. Furthermore, the ultrastructural studies were also performed on freshly isolated cells, and also showed apoptotic cells. This argues that at least some degree of monocyte apoptosis occurs in vivo.

Earlier work suggested that cells other than just lymphocytes undergo apoptosis in SLE patients. The hematoxylin body, characteristic of lupus $(9,10)$, histologically and chemically resembles apoptotic nuclei (11), and is believed to derive from leukocytes, lymphocytes, macrophages, and endothelial cells (10). Apoptotic monocytes and lymphocytes may contribute to the development of this structure. The signal-triggering apoptosis in these cells is unknown. The Fas molecule transmits an apoptosis-inducing signal in lymphocytes and monocytes $(12,13)$, and is functional in SLE patients (13), which suggests a possible mechanism. Since a $T$ cell subset capable of lysing syngeneic macrophages has been described in patients with active lupus (3), and T cells can express a Fas ligand (14), an autoreactive $T$ cell subset could be responsible. Alternatively, monocyte and lymphocyte apoptosis could be the result of as yet unidentified stimuli generated during active disease. In either case, apoptotic cells could contribute to the pathogenesis of the disease. Recent evidence suggests that antiDNA antibodies preferentially react with nucleosomes (15). Nucleosomal DNA fragments, released from apoptotic blood elements, could provide an antigen source contributing to the development of anti-DNA autoantibodies.

Supported by PHS grants AR-42525, AR-08309, and AR-20557, and by grants from the Veterans Administration and the Arthritis Foundation.

Bruce C. Richardson, MD, PhD

University of Michigan and Ann Arbor Veterans Affairs Hospital

Raymond L. Yung, MD

Kent J. Johnson, MD

University of Michigan

Ann Arbor, $M I$

Paul E. Rowse, BS

Narendra D. Lalwani, PhD

Parke-Davis Pharmaceutical Research

Ann Arbor, MI
1. Rumore PM, Steinman CR: Endogenous circulating DNA in systemic lupus erythematosus. J Clin Invest 86:69-74, 1990

2. Emlen W, Niebur J, Kadera R: Accelerated in vitro apoptosis of lymphocytes from patients with systemic lupus erythematosus. J Immunol 152:3685-3692, 1994

3. Richardson BC, Strahler JR, Pivirotto TS, Quddus J, Bayliss GE, Gross LA, O'Rourke KS, Powers D, Hanash SM, Johnson MA: Phenotypic and functional similarities between 5-azacytidinetreated $T$ cells and a $T$ cell subset in patients with active systemic lupus erythematosus. Arthritis Rheum 35:647-662, 1992

4. Yung RL, Quddus J, Chrisp CE, Johnson KJ, Richardson BC: Mechanisms of drug induced lupus. I. Cloned Th2 cells modified with DNA methylation inhibitors in vitro cause autoimmunity in vivo. J Immunol 154:3025-3035, 1995

5. Tan EM, Cohen AS, Fries JF, Masi AT, McShane DJ, Rothfield NF, Schaller JG, Talal N, Winchester RJ: The 1982 revised criteria for the classification of systemic lupus erythematosus. Arthritis Rheum 25:1271-1277, 1982

6. Arnett FC, Edworthy SM, Bloch DA, McShane DJ, Fries JF, Cooper NS, Healey LA, Kaplan SR, Liang MH, Luthra HS, Medsger TA Jr, Mitchell DM, Neustadt DH, Pinals RS, Schaller JG, Sharp JT, Wilder RL, Hunder GG: The American Rheumatism Association 1987 revised criteria for the classification of rheumatoid arthritis. Arthritis Rheum 31:315-324, 1988

7. Dive C, Gregory CD, Phipps DJ, Evans DL, Milner AE, Wyllie AH: Analysis and discrimination of necrosis and apoptosis (programmed cell death) by multiparameter flow cytometry. Biochim Biophys Acta 1133:275-285, 1992

8. Telford WG, King LE, Fraker PJ: Comparative evaluation of several DNA binding dyes in the detection of apoptosis-associated chromatin degradation by flow cytometry. Cytometry 13:137-143, 1992

9. Quismorio FP Jr: Hemic and lymphatic abnormalities in SLE. In, Dubois' Lupus Erythematosus. Fourth edition. Edited by DJ Wallace, BH Hahn. Philadelphia, Lea and Febiger, 1993

10. Klemperer P, Gueft B, Lee SL, Leuchtenberger C, Pollister AW: Cytochemical changes of acute lupus erythematosus. Arch Pathol Lab Med 49:503-516, 1950

11. Cohen AH, Zamboni L: Ultrastructural appearance and morphogenesis of renal glomerular hematoxylin bodies. Am J Pathol 89:105-118, 1977

12. Richardson BC, Lalwani ND, Johnson KJ, Marks RM: Fas ligation triggers apoptosis in macrophages but not endothelial cells. Eur J Immunol 24:2640-2645, 1994

13. Mysler E, Bini P, Drappa J, Ramos P, Friedman SM, Krammer PH, Elkon KB: Apoptosis-1/Fas protein in human systemic lupus erythematosus. J Clin Invest 93:1029-1034, 1994

14. Suda T, Takahashi T, Golstein P, Nagata S: Molecular cloning and expression of the Fas ligand, a novel member of the tumor necrosis factor family. Cell 75:1169-1178, 1993

15. Burlingame RW, Boey ML, Starkebaum G, Rubin RL: The central role of chromatin in autoimmune responses to histones and DNA in systemic lupus erythematosus. J Clin Invest 94:184-192, 1994 